
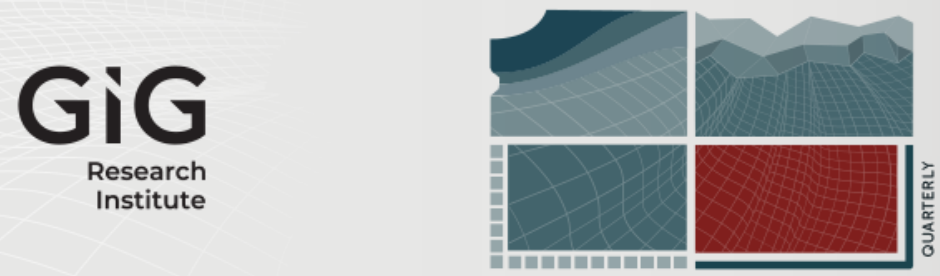

JOURNAL

OF

SUSTAINABLE

MINING

Volume 20 | Issue 4

Article 1

2021

\title{
Decarbonisation - Origins and Evolution of the Process on the European Level
}

Author(s) ORCID Identifier:

Sylwia Jarosławska-Sobór (iD) 0000-0003-0920-6518

Follow this and additional works at: https://jsm.gig.eu/journal-of-sustainable-mining

Part of the Explosives Engineering Commons, Oil, Gas, and Energy Commons, and the Sustainability Commons

\section{Recommended Citation}

Jarosławska-Sobór, Sylwia (2021) "Decarbonisation - Origins and Evolution of the Process on the European Level," Journal of Sustainable Mining: Vol. 20 : Iss. 4 , Article 1.

Available at: https://doi.org/10.46873/2300-3960.1323

This Review is brought to you for free and open access by Journal of Sustainable Mining. It has been accepted for inclusion in Journal of Sustainable Mining by an authorized editor of Journal of Sustainable Mining. 


\title{
Decarbonisation - Origins and Evolution of the Process on the European Level
}

\author{
Abstract \\ Decarbonisation of the european economy is one of the most important megatrends that will shape \\ economic and social development in the coming years. This paper discusses the basic concepts of \\ decarbonisation in terms of climate change, the history of this idea development and the legal basis \\ introduced in the European Union, including key European documents and tools influencing the process, \\ like ETS or $\mathrm{CO} 2$ emission allowances. Background on decarbonisation has been presented as a European \\ roadmap to achieve a low-carbon economy in Europe. In the article the main assumptions of the EU \\ strategy papers like Clean Energy for All Europeans or the European Green Deal are presented. Casus \\ Silesia indicates the basic problematic issues that coal regions will have to tackle to due to the transition \\ away from coal. For European societies, the new environmental policy of the European Commission \\ means the intensification of activities to reduce greenhouse gas emissions and switching the economy to \\ low- or zero-carbon energy sources and technologies. The decarbonisation of the economy is an ongoing \\ process which has been gaining momentum in recent years. The coal transition is a huge challenge, \\ particularly for Poland.

\section{Keywords} \\ decarbonisation, coal transition, $\mathrm{CO} 2$ emission, climate change, low-carbon, energy regulations \\ Creative Commons License \\ (c) (†) \\ This work is licensed under a Creative Commons Attribution 4.0 License.
}




\title{
Decarbonisation - Origins and evolution of the process on the European level
}

\author{
Sylwia Jarosławska-Sobór
}

Central Mining Institute (GIG), Plac Gwarków 1, 40-166, Katowice, Poland

\begin{abstract}
Decarbonisation of the european economy is one of the most important megatrends that will shape economic and social development in the coming years. This paper discusses the basic concepts of decarbonisation in terms of climate change, the history of this idea development and the legal basis introduced in the European Union, including key European documents and tools influencing the process, like ETS or $\mathrm{CO}_{2}$ emission allowances. Background on decarbonisation has been presented as a European roadmap to achieve a low-carbon economy in Europe. In the article the main assumptions of the EU strategy papers like Clean Energy for All Europeans or the European Green Deal are presented. Casus Silesia indicates the basic problematic issues that coal regions will have to tackle to due to the transition away from coal. For European societies, the new environmental policy of the European Commission means the intensification of activities to reduce greenhouse gas emissions and switching the economy to low- or zero-carbon energy sources and technologies. The decarbonisation of the economy is an ongoing process which has been gaining momentum in recent years. The coal transition is a huge challenge, particularly for Poland.
\end{abstract}

Keywords: decarbonisation, coal transition, $\mathrm{CO}_{2}$ emission, climate change, low-carbon, energy regulations

\section{Introduction}

$\mathrm{D}$ emographic trends indicate that there will be 9.7 billion people in the world by 2050 . Given limited natural resources and climate change, it is advisable to develop new consumption patterns, especially where they are related to the use of natural resources. In 2015, human population consumed as much natural resources as would be found on 1.6 of the planet [1].

Decarbonisation of the economy is one of the most important megatrends that will shape economic and social development in the coming years. As one of the five priorities of the energy union, its axis is centred around the countries of the European Union. Hence, it is also referred to as the European economic model. In its simplest sense, this model is characterised by a systematic decrease in the use of coal in the energy sector and economy in general. Decarbonisation means, therefore, systematic reduction of electricity production from coal due to social and environmental damage caused by the use of this raw material in the economy. The process was initiated and intensified on the grounds of the European energy policy [2]. This paper discusses the basic concepts of decarbonisation, the history of this idea development and the legal basis introduced in the European Union, including key documents and tools influencing the process. It also indicates the basic problematic issues which Silesia faces due to the transition away from coal.

\section{Materials and methods}

In the paper has been used desk research methodology as a qualitative research. For the analysis of the decarbonisation process the EU strategy papers was revised. For the analysis of background on decarbonisation in terms of climate change was reviewed key document of global stakeholders, such as United Nations and UN Environment Programme (UNEP), United Nations Framework Convention on Climate Change (UNFCC) or the Intergovernmental Panel on Climate Change (IPCC) documents. The literature review covered global publications related to the target problem. 


\section{Decarbonisation - concept and assumptions}

In EU terms, decarbonisation means a policy to combat climate change and strive to become a leader in renewable energy [3]. This policy implies that various measures should be taken aimed at creating an integrated energy market and ensuring security of energy supply and sustainability of the energy sector. It is the response of European countries to the challenges in the field of energy, related to insufficient diversification, high and volatile energy prices, growing global demand for energy, threats to the security of production and transit, climate change, low rate of progress in energy efficiency, challenges related to the growing use of renewable energy sources and the need for greater transparency in energy markets [4]. What is important, however, is that the instruments to support decarbonisation policies are in the form of restrictive legal and financial regulations.

The basis for introducing such a policy is to intensify efforts to reduce the use of coal in the economy. For many years, coal was, and for many economies still is, a fundamental raw material for energy. Its main advantages include its availability, attractiveness in terms of price, technological possibilities and long-term sufficiency. In spite of this, its widespread use currently gives rise to many controversies, primarily of a social and ecological nature [5]. The use of coal for energy purposes is primarily associated with the emission of carbon dioxide $\left(\mathrm{CO}_{2}\right)$, the most common greenhouse gas responsible for climate change. What are greenhouse gases in general? Greenhouse gases, mainly carbon dioxide, methane, but also nitrous oxide and CFCs, are gases which absorb the energy and heat from the sun which radiate from the surface of the Earth, trapping it in the atmosphere and preventing it from escaping into space. This process is the main cause of the greenhouse effect, which keeps the temperature of the Earth higher. Many greenhouse gases occur naturally in the atmosphere, but human activity increases their amounts, increasing the greenhouse effect which in turn contributes to global warming [6].

\subsection{Background on decarbonisation in terms of climate change}

The first UN conference on environmental issues and climate problems was held in 1972 in Stockholm. Organised under the slogan 'Only One Earth', it marked a turning point in the development of international environmental policy [7]. Environ mental protection was raised to the status of a basic function of the state and the United Nations Environment Programme (UNEP) was established. In 1979, the first international meeting on climate change was held, which led to the establishment of the World Climate Programme [8].

The Intergovernmental Panel on Climate Change (IPCC), a scientific, intergovernmental organisation set up under the auspices of the United Nations, was established in 1988 [9] Its objective is to provide the international community with information on the state of scientific knowledge on climate change and its potential environmental, economic and social impacts. To date, the IPCC has issued six reports on climate risks, and the recommendations of the reports are the basis for binding decisions, including the Paris Agreement in 2015.

Another important step was the United Nations Conference on 'Environment and Development', a conference held in 1992 in Rio de Janeiro with the participation of leaders and representatives of 162 countries and international organisations, often referred to as the 'Earth Summit'. It is widely considered that the era of eco-development has started with the adoption of important documents, including the Rio Declaration on Environment and Development. It also adopted the Agenda 21, the Comprehensive Plan of Action [10] and the United Nations Framework Convention on Climate Change (UNFCCC), which aims to protect the climate and reduce global greenhouse gas emissions [11]. Collective action led to the first Conference of the Parties (COP1) in 1995 in Berlin [12], (UN, 1995), which recognised that the commitments in the Climate Convention were inadequate in relation to the targets previously set, and the signing of the Kyoto Protocol in 1997. The Protocol was the first global treaty to reduce greenhouse gases and committed developed countries to reduce gas emissions by an average of $5 \%$ by 2012 compared to 1990 emissions [13]. Climate conferences of the Parties is the most important body of the United Nations Framework Convention on climate change. The COP oversees the implementation of the Convention by individual countries and also develops new provisions in the form of decisions.

In 2005, an important climate policy tool emerged. The EU Emissions Trading Scheme (EU ETS) was launched with the aim of reducing carbon dioxide emissions from industry through the use of restrictive financial instruments [14]. (The European Emissions Trading Scheme (ETS) obliges more than 11,000 power plants and factories in the European Union to hold a permit for every tonne of $\mathrm{CO}_{2}$. 
Until 2013, each installation received free emission allowances within limits, set locally and approved for the country collectively at EU level. Since 2013, the allowance allocation system has changed significantly. Each year the number of allowances decreases by $1.74 \%$. A list of energy-intensive industries has been identified, comprising 177 sectors (carbon leakage industries, i.e. sectors particularly vulnerable to relocation outside the Union), which have been allocated free emission allowances until 2020 [15]. Some countries, including Poland, have additionally negotiated the possibility to transfer free allowances to the energy sector. At the EU-wide level, the amount of free allowances in 2020 should represent $30 \%$ of allowances [16]. The remaining allowances necessary to maintain production can be purchased by companies on the exchange. At the moment, allowance prices are around EUR 24 per 1 tonne of $\mathrm{CO}_{2}$ emissions and this price has risen steadily since 2014 (see Fig. 1).

For every industrial plant emitting carbon dioxide in the EU, this means multi-million costs. Either the plant will carry out costly modernisations that will increase combustion efficiency and thus reduce emissions, or it will have to spend considerable sums on purchasing allowances for additional $\mathrm{CO}_{2}$ emissions on the stock exchange. Therefore, even if the EU does not formally ban the use of coal in combustion processes in the power industry i.e. energy sector, the system for purchasing $\mathrm{CO}_{2}$ emission rights is very burdensome.

At the end of 2017, EU countries agreed to deregulate energy prices in the European market and create a so-called capacity market. This was supposed to improve competitiveness and reduce prices. In the Polish reality, the capacity market was to support coal-based energy sector and benefit from support mechanisms until 2030. The emission limit for power units which may receive public support was set at $550 \mathrm{~g} / \mathrm{kWh}$. This limit is still too high for Polish solutions. Currently, coal-fired units in Poland produce more than $900 \mathrm{~kg} / \mathrm{MWh}$ of $\mathrm{CO}_{2}$ emissions (Fig. 2).

A milestone was the signing in 2015 of Paris Agreement, the first ever universal and legally binding international agreement [19]. The agreement aims to keep the increase in global average temperatures well below $2{ }^{\circ} \mathrm{C}$ compared to the preindustrial era and to continue efforts to limit temperature increases to $1.5^{\circ} \mathrm{C}$ above pre-industrial levels. The signing countries wanted to reach a point where greenhouse gas emissions stop rising as soon as possible and to balance gas emissions and absorption in the second half of the century. The agreement places emphasis on reducing the concentration of $\mathrm{CO}_{2}$ in the atmosphere as quickly and effectively as possible, in order to improve water and air quality, discontinue desertification and the loss of biodiversity. It assumes that actions to reduce $\mathrm{CO}_{2}$ concentrations will be taken by all the parties to the agreement, with respect for their specific characteristics and socio-economic possibilities. The Paris Agreement also states that during this period we should achieve a balance between greenhouse gas emissions and its absorption by i.e. forests.

For Poland, and especially for the Silesian region, an important event was COP24, which was held in Katowice from 2 to 16 December 2018. During the

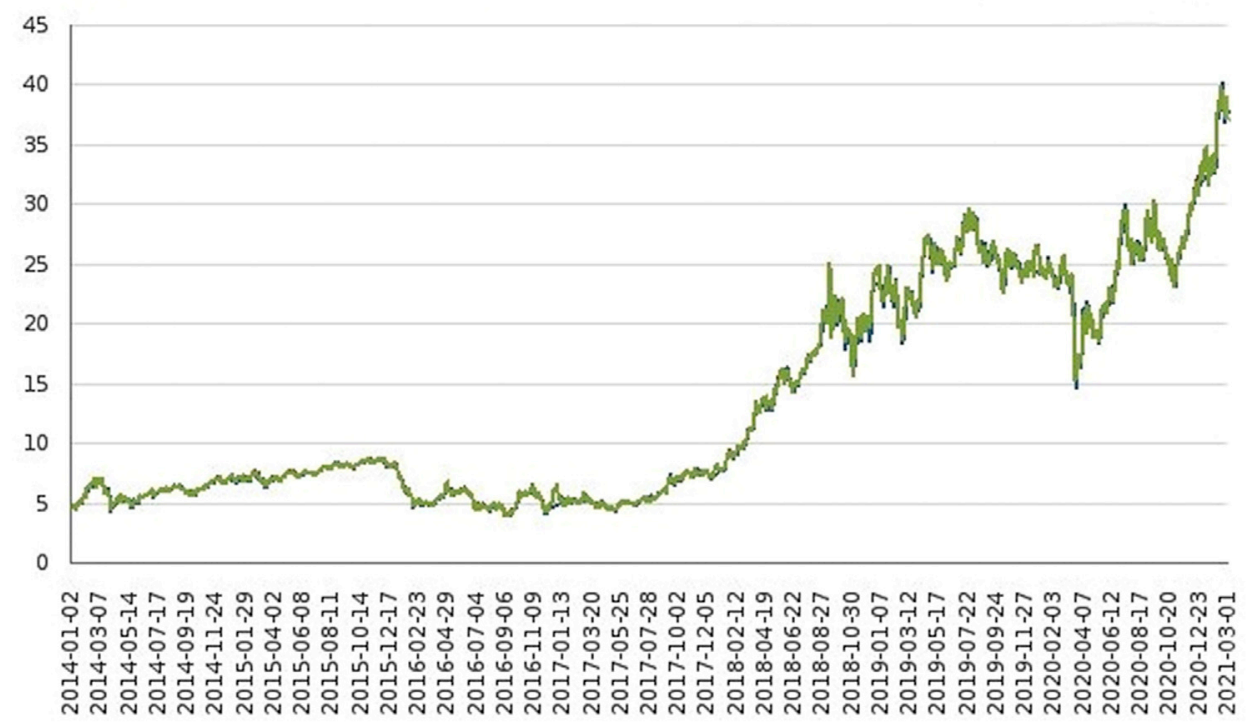

Fig. 1. Change in $\mathrm{CO}_{2}$ emission allowance prices in years 2014-2021 [17], https://handel-emisjami-co2.cire.pl/retrieved 18.03.2021. 


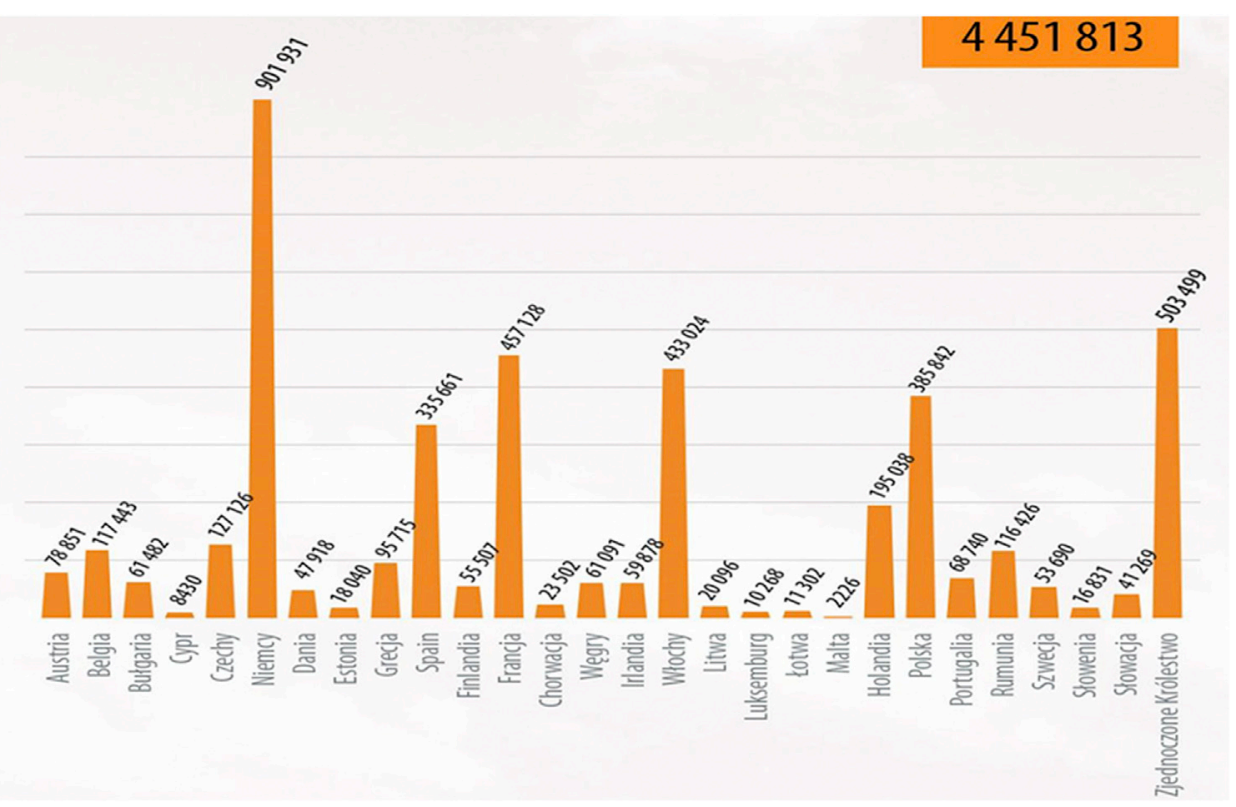

Fig. 2. Greenhouse gas emissions by EU country in kilo tonnes of $\mathrm{CO}_{2}$ equivalent, according to the European Environment Agency and Eurostat [18].

conference, the so-called Talanoa Dialogue on more effective climate action was upheld which was introduced into official negotiations by the Fijian Presidency at COP23 [20]. An agreement on the detailed rules for implementing the Paris Agreement were developed in Katowice, which was referred to as the 'Katowice Rulebook'. Among other things, the document contains information on national mitigation targets and actions taken under the National Action Programmes. The Paris Agreement is to be implemented precisely thanks to individually determined so-called national contributions (NDCs), taking into account the national economic, social and natural conditions of individual countries, as well as their development goals. Reporting methods, common measures and a system containing data on emission reductions were also adopted. Another important element of the Katowice Rulebook is to determine the shape of the Global Stocktake, which is to be carried out in 2023 and form the basis for the preparation of reduction plans after 2030. The package highlights the urgent need for developed countries to increase their funding, access to technology and support to strengthen the efforts of developing countries. The call for increased ambition covers the years beyond 2020 and a commitment of US\$100 billion in funding per year [21] The document adopts the Solidarity and Just Transition Silesian Declaration, which emphasises the need to ensure the creation of new, high quality jobs. The agreement does not talk about reducing $\mathrm{CO}_{2}$ emissions as the only way to tackle climate change. It also points to the absorption of carbon dioxide by living natural resources such as forests.

European trade unions have also developed their own challenge statement for COP24. The unions want governments to commit to a just transition whereby workers are part of the solution aimed at meeting climate change targets. Three main aspects of this process are identified:

1. The need for sustainable industrial policy at national and regional level, including programmes for the adaptation of workers to new conditions.

2. Strengthening the range of social programmes and safeguards, including health and welfare, unemployment insurance, pensions, education, re-education, training and retraining, but also comprehensive lifelong learning systems.

3. The need for adaptation programmes to strengthen the capacity and capabilities of the workforce to achieve sustainable development [22].

It is necessary to stress that not all countries were and are supporters of the climate policies pursued. In 2017, President Donald Trump announced his willingness to withdraw the US from the Paris Agreement [23], just as President George W. Bush withdrew the US from the Kyoto Protocol in 2001 [24], which in his view imposed a greater reduction burden on developed countries than on developing ones. A new US approach to climate policy has been 
announced by new President Joe Biden, who as early as in December 2020 promised to raise US reduction targets and embark on a path towards climate neutrality by 2050 [25].

The global use of coal in the economies of other countries is not declining either. According to the International Energy Agency, between 2016 and 2017, increases in coal use were recorded in India (by 40 million $\mathrm{t}$ ), Korea ( 15 million $\mathrm{t})$, Russia and China (10 million $t$ ) and Indonesia (over 6 million $t$ ), while decreases were recorded in Colombia and the UK (2-3 million $t)$, Ukraine (7 million $t)$, Germany (over 9 million $t$ ) and the US (17 million $t$ ). Global electricity generation on coal increased by more than $250 \mathrm{TWh}$, that is about $3 \%$, and accounted to about $40 \%$ of new capacity [26].

Spanish study shows the environmental impacts of the decarbonisation plan proposed by the Spanish Government in the individual dimension. Using the LCA methodology, of the electricity consumption to supply the heating and cooling demands of a reference single-family house it shows the effects led to a reduction of the damage in the categories Human Health - 59-68\%, Climate Change - 57 up to $67 \%$ and Resources - from 54 up $65 \%$ [27].

\subsection{EU legal basis for decarbonisation}

Legislation putting decarbonisation policy on a new track in the EU emerged in 2008. The European Parliament supported a package of six legislative proposal which enable the achievement of overall targets to combat climate change. The main objectives of the climate package, also known as $3 \times 20$, were:

- to reduce greenhouse gas emissions by $20 \%$ until 2020,

- increase the share of renewable energy sources (RES) in the energy mix to $20 \%$, with three main economy sectors: electricity generation, heat engineering and transport,

- increasing energy efficiency by $20 \%$ by reducing transmission losses and increasing efficiency in energy generation.

For Poland, the RES share target has been set at $5 \%$ lower [28].

These solutions were followed in 2009 by Directive 2009/29/EC of the European Parliament and of the Council to improve and extend the greenhouse gas emission allowance trading scheme of the Community EU ETS Directive [29]. It set $\mathrm{CO}_{2}$ limits for the period 2012-2020 and rules for emissions trading for power and heat units with a rated thermal input exceeding $20 \mathrm{MW}$. It assumed that all emission allowances not allocated for free must be auctioned. It was supported by Directive 2009/28/EC on the promotion of the use of energy from RES [30]. It defines a common framework for Member States as well as sets mandatory national targets for the share of energy from RES in total gross final consumption of energy. Poland's target was to achieve a share of renewable energy in gross final energy consumption of $15 \%$ in 2020 .

In 2010, another EU Directive 2010/75/EC on industrial emissions, the so-called IED [31], was introduced. It introduced a number of significant changes to the existing regulations on integrated environmental protection. It significantly tightened standards, setting several times lower standards for emissions of sulphur dioxide, nitrogen oxides and dust for combustion plants with a rated thermal input exceeding $50 \mathrm{MW}$.

The new climate package, the so-called 'winter package' and the concept of an energy union have become another important step on the road to decarbonisation policy.

\subsection{The energy union and the winter package}

In 2016, European Commission proposed the 'Clean Energy for All Europeans' package [32], where measures to improve energy efficiency are part of the so-called Juncker Plan. In 2014, JeanClaude Juncker in his political programme identified the plan to create an energy union as one of the ten priorities of the new European Commission [33].

The Clean Energy Package includes eight legislative proposals on issues such as governance, electricity market design (the Electricity Directive, the Electricity Regulation and the Emergency Preparedness Regulation), energy efficiency, energy performance of buildings, renewable energy and provisions for the Agency for the Cooperation of Energy Regulators. The five most important EU energy policy objectives are:

1. ensuring the functioning of the internal energy market and guaranteeing interconnections;

2. ensure security of energy supply in the Union;

3. promote energy efficiency and energy savings;

4. promote the development of new and renewable forms of energy to better align and integrate climate change objectives with the new market structure; and

5. promote research, innovation and compet itiveness. 
The basis for the adopted concept of energy union was the Treaty on the Functioning of the European Union and its specific provisions on security of supply, energy networks, the role of coal and nuclear energy. Article 194 of the Treaty brings certain areas of energy policy under shared competence, signalling a move towards a common energy policy. But at the same time, each Member State retains the right to determine the conditions for the use of its energy resources, the choice between different energy sources and the overall structure of its energy supply [34].

The energy regulations adopted under the Juncker Plan are also known as the 'winter package'. It is practically a continuation of the EU climate and energy policy from $2008(3 \times 20)$. A new element of the winter package are proposals for tools to enable an increase in climate targets in the 2030 perspective, including:

- a reduction of at least $40 \%$ of the economy-wide internal greenhouse gas emissions compared to 1990, translating this target into emission reductions of $43 \%$ in the ETS sectors and $30 \%$ in the non-ETS sectors compared to 2005,

- raising the share of RES energy in the total energy consumption to at least $27 \%$,

- improving energy efficiency by at least $27 \%$, with a recommendation to consider raising it to $30 \%$ by 2030 .

The EU's declared outcome of implementing the Winter Package targets is to enable access to cleaner energy for all, to implement the Paris Agreement 2015, to stimulate economic growth by making the EU a leader in investment and technology, and to create new employment opportunities and ultimately increase the well-being of citizens According to the estimates by the European Commission, the implementation of the energy and climate objectives will require an expenditure of approximately EUR 379 billion per year between 2020 and 2030. In addition, according to preliminary assessments, approximately EUR 27 billion per year will need to be spent on research and development and innovation in energy union-related fields each year [35].

The European Parliament has set new binding targets for energy efficiency and renewable energy use by 2030 on 17 January 2018, which was set out in an analysis 'A Clean Planet for all' [36]. MEPs voted to improve energy efficiency in the EU by $35 \%$, increase the share of renewable energy to at least $35 \%$ of total consumption and ban palm oil in biofuels from 2021 [37]. Each Member State will also have to meet binding annual emission reduction targets between 2021 and 2030. These targets are calculated on the basis of GDP per capita: between $0 \%$ and $40 \%$ below 2005 levels and are in line with the overall $30 \%$ EU reduction target [38].

The regulation on the governance of the energy union specifies that the governance system will have two levels. Firstly, it will consist in the mandatory presentation of 10-year integrated national energy and climate plans. All member states are to propose how they will achieve EU policy objectives by 2030, and the first such plan should be received by the European Commission by the end of 2019. Secondly, the Commission will give its opinion on these plans and then check on the basis of biennial reports that they are being implemented. Each Member State is also to present by January 1st 2020, a low-carbon strategy by 2050, which is to be, in effect, a plan for the decarbonisation of the economy in accordance with the Paris Agreement. The conclusions stipulated that the energy governance system was to be flexible and designed to respect the rights of member states to freely determine their energy mixes, but it was also clear that it would require coordination with the European Commission and consequently strengthen its oversight (Fig. 3).

The regulation shows the growing power of the European Commission and the direction in which EU climate policy is developing. Between 2021 and $2027,25 \%$ of the EU budget will be allocated to climate protection, and the inclusion of this priority is formulated in relation to trade policy (import charges from countries that do not reduce emissions), or macroeconomic policy ('greening' of the European area), and even agricultural policy. The Regulation makes it clear that pro-climate action should be a key factor in the growth of the economies of the Member States and the Union as a whole [39].

\subsection{European Green Deal}

On December 11th 2019, Ursula von der Leyen, the new President of the European Commission, presented the principles of the European Green Deal for the European Union and its citizens (EU Green Deal), that is the European Union's comprehensive strategy to protect the environment and combat climate change. The overall objectives of the strategy concern the economic transformation of the member states and its transformation into a society living in a modern, resource-efficient and competitive economy [41]. The main objective is to achieve climate neutrality by 2050 and zero net greenhouse gas emissions. The European Green Deal consists of 10 goals, two of which directly address the issue of decarbonisation, i.e. achieving climate neutrality 


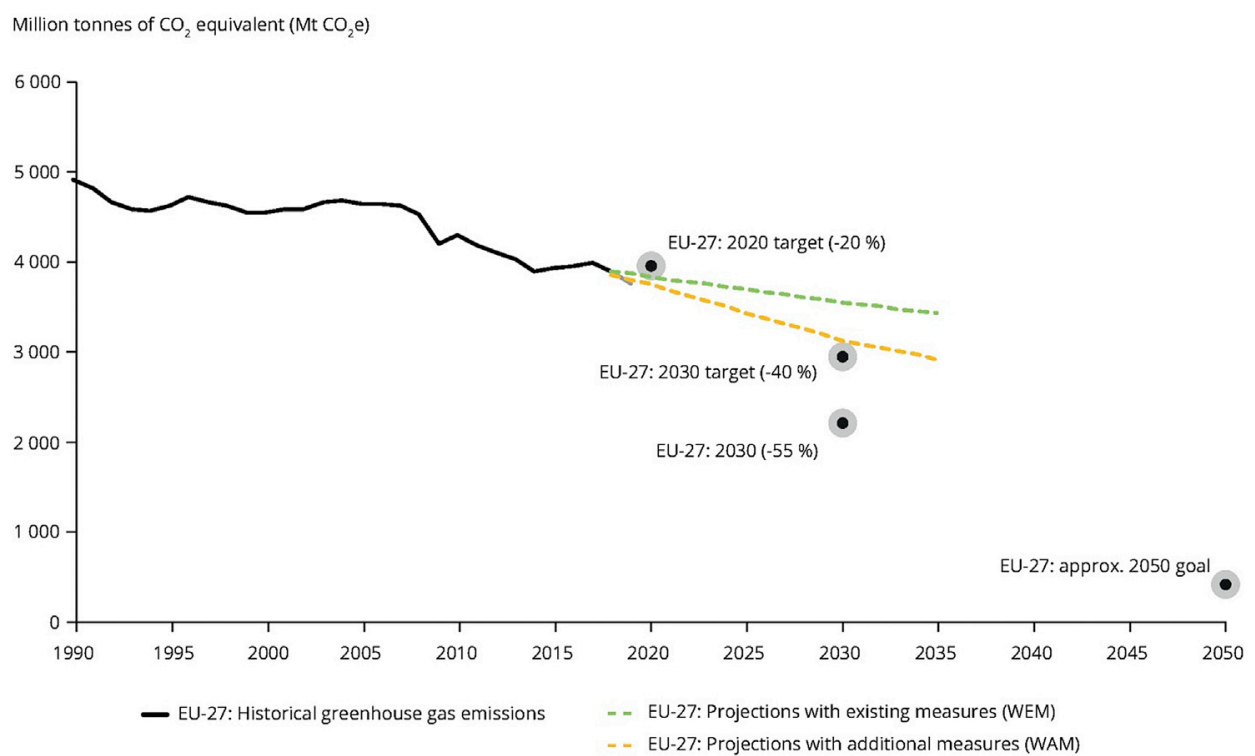

Fig. 3. Greenhouse gas emission targets, trends, and Member States MMR projections in the EU 1990-2050, according to the European Environment Agency [40].

and the JUST Transition mechanism, i.e. financial support for regional energy transition plans. According to these provisions, Europe has underlined its aspiration to be the first climate-neutral continent by 2050 [42].

The goal of climate neutrality has been endorsed by the European Parliament and the European Council and, as a result, a European Climate Law was proposed in March 2020, a new regulation currently in the legislative process [43]. Proposals for action in all sectors of the economy have also been prepared, such as investing in environmentally friendly technologies, promoting industrial innovation, introducing cleaner, cheaper and healthier forms of private and public transport, decarbonising the energy sector, ensuring greater energy efficiency in buildings and working with international partners to improve global environmental standards. Financial support and technological assistance for the regions that will be most affected by the changes associated with the Green Deal goals is to be provided by The Just Transition Mechanism, which allocates $€ 100$ billion for assistance between 2021 and 2027 [44] It has three pillars: a new Just Transition Fund with a budget of $€ 40$ billion [45], an InvestEU Just Transition scheme to mobilise $€ 45$ billion of investment [46], and an EIB Public Sector Loan Facility with a budget of $€ 10$ billion [47], supported by $€ 1.5$ billion from the EU budget, to mobilise up to $€ 30$ billion of investment.

The Covid-19 virus pandemic in 2020 did not inhibit the direction of decarbonisation efforts in Europe, and indeed it is emphasised that the EU's transition towards climate neutrality will play a central role in the recovery from the coronavirus crisis [48]. In order to meet the goal of the EU becoming climate neutral by 2050, in December 2020 European Council endorsed a new binding EU target to reduce net domestic greenhouse gas emissions by at least $55 \%$ by 2030 compared to 1990 levels [49]. This is $15 \%$ points higher than the target agreed in 2014. Current EU law obliges EU countries to collectively reduce greenhouse gas emissions by 40 percent compared to 1990, increase the share of renewable energy to $32 \%$ and reduce energy demand by $32.5 \%$. This will entail reducing the rate of growth of energy demand, but also increasing the share of renewable energy and introducing stricter regulations on emissions from industry, transport and agriculture.

In order to continue on the course it has set for its climate policy, the European Union must face up to serious competition from operators outside the Union and prevent carbon leakage. This problem has become particularly relevant during the coronavirus crisis, at a time when the major global powers are sinking into recession, which may result in an even more aggressive strategy of action that will not be compatible with the green deal. According to Think Tank analysis, Carbon Tracker cites the example of China, which is considering building new coal capacity on an even larger scale. Already $99.7 \mathrm{GW}$ of coal-based capacity is under construction, with another 106.1 GW under consideration. This potential represents 23 billion tonnes of $\mathrm{CO}_{2}$ [50]. The European Commission has 
therefore started to work on Carbon Border Adjustment Mechanism - CBAM [51]. On July 14th, 2021 the European Commission proposed new package Fit for 55 its key part the Carbon Border Adjustment Mechanism, as a climate measure that should prevent the risk of carbon leakage and support the EU's increased ambition on climate mitigation [52]. Primary objectives of CBAMs is to support the reduction of GHG emission in the European Union and to ensure that emissions reductions in the EU lead to emissions reductions globally [53]. The CBAM will impose a levy on imports in carbon-intensive sectors like steel, cement and fertilizers from countries with lower environmental standards than the EU. From 2026, importers will have to purchase special certificates to cover their carbon emissions at prices corresponding to the current carbon price within EU ETS system.

\subsection{Casus Silesia}

Although the decarbonisation policy applies to the whole of the Union, in the context of Poland it is considered primarily from the point of view of Silesia. This region, which homes majority of active coal mines in Poland and is going to carry the greatest burden of coal transition. Due to spatial concentration of hard coal mining, closure of collieries might have a strong negative impact on local labour markets with outcomes such as persistently increased unemployment rates and intensification of social exclusion [54]. Mainly due to the concentration here of practically all, apart from Bogdanka mine, hard coal mines still existing in Poland. Direct employment in the mining industry amounted to 82.8 thousand employees at the end of 2018, and it is estimated that there are four jobs in the mining industry per one job in mining-related industry. In 2018, the University of Economics in Katowice presented a model for valuing the cost of replacing mining jobs with equivalent jobs in another sector. In the transformation scenario, the average cost of replacing one job in the coal sector was calculated at PLN 1.2 million and the total amount was calculated at PLN 190 billion. The scenario envisages the closure of mines with the simultaneous need for investment for new jobs in the automotive, construction services, logistics or RES sectors [55].

The reports of WWF Poland and Wise Europa emphasise that the challenges entail a deep reconstruction of the economic structure of the region, and in particular a reduction in the significance of hard coal mining, heavy industry and traditional, conventional power generation. The authors point out that, according to trends and detailed forecasts of the profitability of mining in Upper Silesian mines, energy coal mining will disappear by 2050 . Overall, by 2050 the number of jobs in mining will fall below 10,000 and will be more than seven times lower than today [56].

Also, reports by the Institute for Structural Research (IBS) indicate that the coal transition will profoundly transform the labour market of the region, but the social and economic challenges will be less significant than in the 1990s. They show that the number of miners will decrease by about 50,000 between 2015 and 1940, but these will mostly be departures due to natural causes [57]. The transition resulting from decarbonisation is assumed to be spread over time. In 2018, the IBS assumed that the decline in mining employment would be rapid enough to avoid layoffs related to the decline in coal demand, but provided that the supply of new workers to the mining sector is limited and that public policies on education can play a large role [58]. In 2021, the IBS highlights that, depending on the adopted decarbonisation scenario for the Polish economy, the number of workers that will need to be supported will vary between 14,000 and 36,000 by 2030, which may result in new labour supply mismatches in the industry in the mid-2030s. There will be insufficient use of the natural retirement process and the number of workers who will require relocation or depend on the pace of decarbonisation [59]. On the other hand, however, some experts see potential in the coming changes. In 2018, a JRC report estimated that the European coal sector, which employs nearly 500,000 people, should expect to see 160,000 fewer jobs by 2030 [60]. In 2020, a new JRC report indicates that in more than half of the mining regions, the energy transition could generate more jobs than are currently found in the coal sector, which the authors of the report estimate at 315000 jobs by 2030 and 460000 in 2050. Such potential is seen by experts in the RES market [61]. However, the greatest fears of Polish experts have remained the same for years and concern a decrease in the number of companies, an increase in unemployment and a decrease in revenues from taxes, fees or dividends, which may significantly translate into a decrease in the level of state revenues and entail a decrease in the ability to finance projects related to ecology and environmental protection [62].

\section{Conclusions}

There is no doubt that the decarbonisation of the economy is an ongoing process which has been gaining momentum in recent years. The European 
Union does not formally ban the use of coal in energy processes, but the ETS system, which is linked to the purchase of $\mathrm{CO}_{2}$ emission allowances and the rising prices of these allowances, is placing the greatest burden on the coal-based energy sector. The end of the system of free emission allowances means problems with high prices for consumers and a lack of competitiveness in the market. For European societies, the new environmental policy of the European Commission means the intensification of activities to reduce greenhouse gas emissions, which are the main cause of global warming, and switching the economy to low- or zero-carbon energy sources and technologies. Decision-making bodies with an appropriate level of decision-making, including economic decision-making, which supports the implementation of solutions and innovations in the area of decarbonisation, play an important role here.

The transition from a coal-based economy to the one based on renewable energy systems is a huge challenge, particularly for Poland. The changes in the coming years will have to be more dynamic than in any other European countries with adequate natural potential for RES. Achieving climate neutrality will require a huge investment effort and a change in the structure of the Polish economy, while at the same time proper planning of the transformation process so that it actually meets the expectations of the just transition.

\section{Conflicts of interest}

None declared.

\section{Ethical statement}

The author state that the research was conducted according to ethical standards.

\section{Funding body}

None.

\section{References}

[1] EY. The Upside of Disruption. Megatrends shaping 2016 and beyond, retrived. 2016. ey.com/megatrends.

[2] Kaliski M, Szurlej A, Grudziński Z. Węgiel i gaz ziemny w produkcji energii elektrycznej Polski i UE. In: Polityka Energetyczna, t. 15, z. 4, 2012 UE, Polityka energetyczna, zasady ogólne; 2012.

[3] Juncker JC. Program polityczny Nowy początek dla Europy: Mój program na rzecz zatrudnienia, wzrostu, sprawiedliwości oraz zmian demokratycznych. In: Wytyczne polityczne na następną kadencję Komisji Europejskiej; 2014.

[4] European Parliament. Polityka energetyczna. Zasady ogólne. 2013. http://www.europarl.europa.eu/RegData/etudes/ fiches_techniques/2013/050701/04A_FT(2013)050701_PL.pdf.
[5] Jonek-Kowalska I, Wolny M, Sojda A. Analiza trendów i korelacji cen węgla kamiennego na rynkach międzynarodowych w erze dekarbonizacji. Zeszyty naukowe Politechniki Śląskiej Z. 2014;74. Nr. 1921.

[6] European Commission. Information brochure on greenhouse gases. 2009. https://ec.europa.eu/clima/sites/ campaign/pdf/gases_pl.pdf.

[7] United Nations. United Nations conference on the human environment. 1972. https://sustainabledevelopment.un.org/ milestones/humanenvironment.

[8] UNESCO. Declaration of the world climate conference. 1979. https://unesdoc.unesco.org/ark:/48223/pf0000037648.

[9] IPCC. United Nations the intergovernmental Panel on climate change. 1988. https://www.ipcc.ch/.

[10] United Nations. Conference on environment and development-UNCED. 1992. https://www.unsystem.org/content/ united-nations-conference-environment-and-developmentunced-1992.

[11] UNFCCC. United Nations history of the Kyoto Protocol. 1992. https://unfccc.int/process/the-kyoto-protocol/historyof-the-kyoto-protocol.

[12] United Nations. 1995. http://www.blue-growth.org/Events Blue_Growth/United_Nations_Climate_Change_ Conferences/COP_1_1995_UN_Climate_Change Conferences Berlin.htm.

[13] UNFCCC. United Nations United Nations climate change. 2008 https://unfccc.int/resource/docs/publications/08_ unfccc_kp_ref_manual.pdf.

[14] European Commission. Cross-Boundary Heat Flows, Guidance Document $n^{\circ} 6$ on the harmonized free allocation methodology for the EU-ETS. 2012. https://ec.europa.eu/ clima/sites/clima/files/ets/allowances/docs/gd6_cross_ boundary_heat_flows_en.pdf.

[15] European Commission. Carbon leakage. 2014. https://ec. europa.eu/clima/policies/ets/allowances/leakage_pl.

[16] European Commission. Commission Decision of 27 April 2011determining transitional Union-wide rules for harmonised free allocation of emission allowances pursuant to Article 10a of Directive 2003/87/EC of the European Parliament and of the Council.2011.https://eur-lex.europa.eu/legal-content/PL/ TXT/PDF/?uri=CELEX:32011D0278\&from=EN.

[17] https://handel-emisjami-co2.cire.pl/.

[18] European parliament. 2018. https://www.europarl.europa. eu/news/pl/headlines/society/20180301STO98928/ infografika-emisje-gazow-cieplarnianych-w-uniieuropejskiej.

[19] UNFCC. United Nations the Paris agreement. 2015. https:// unfccc.int/process-and-meetings/the-paris-agreement/theparis-agreement.

[20] UNFCC. United Nations 2018. 2018. https://unfccc.int/ process-and-meetings/the-paris-agreement/the-parisagreement/2018-talanoa-dialogue-platform.

[21] UNFCC. United Nations the Katowice climate package. 2018. https://unfccc.int/process-and-meetings/the-parisagreement/katowice-climate-package.

[22] IndustriALL makes joint declaration demanding Just Transition at COP24. http://www.industriall-union.org/industriallmakes-joint-declaration-demanding-just-transition-at-cop24.

[23] White house statement by president Trump on the Paris climate accord. https://www.whitehouse.gov/briefingsstatements/statement-president-trump-paris-climateaccord/.

[24] White house president bush discusses global climate change. https://georgewbush-whitehouse.archives.gov/news/ releases/2001/06/20010611-2.html.

[25] White house. https://www.whitehouse.gov/briefing-room/ statements-releases/2021/01/27/fact-sheet-president-bidentakes-executive-actions-to-tackle-the-climate-crisis-athome-and-abroad-create-jobs-and-restore-scientificintegrity-across-federal-government/.

[26] International Coal Agency. Coal. 2018. https://www.iea.org/ coal2018/. 
[27] González-Prieto D, Fernández-Nav Y, Marañón E, Prieto MM. Effect of decarbonisation policies and climate change on environmental impacts due to heating and cooling in a single-family house. Sustainability 2020. https://doi.org/ 10.3390/su12093529. 12/3529.

[28] Urząd Regulacji Energetyki. 2008. https://www.ure.gov.pl/pl/ urzad/wspolpraca-miedzynarod/2829,ParlamentEuropejski-zatwierdzil-pakiet-klimatyczny.html.

[29] European Parliament. Directive2009/29/EC of the European Parliament and of the Council of 23 April 2009amending Directive 2003/87/EC so as to improve and extend the greenhouse gas emission allowance trading scheme of the Community. 2009. https://eur-lex.europa.eu/legal-content/ PL/TXT/PDF/?uri=CELEX:32009L0029\&from $=$ EN.

[30] European Parliament. Directive 2009/28/EC of the European Parliament and of the Council of 23 April 2009 on the promotion of the use of energy from renewable sources and amending and subsequently repealing Directives 2001/77/EC and 2003/30/EC. 2009. https://eur-lex. europa.eu/legal-content/EN/TXT/PDF/?uri=CELEX: 32009L0028\&from $=$ EN.

[31] European Parliament. Directive 2010/75/EU of the European Parliament and of the Council of 24 November 2010 on industrial emissions (integrated pollution prevention and control). 2010.

[32] European Commission. Clean energy for all Europeans. 2016. https://ec.europa.eu/transparency/regdoc/rep/1/2016/ EN/COM-2016-860-F1-EN-MAIN.PDF.

[33] European Commission. The investment plan for Europe (the Juncker plan). 2016. https://ec.europa.eu/commission/ priorities/jobs-growth-and-investment/investment-planeurope-juncker-plan_pl.

[34] European Parliament. Consolidated versions of the treaty on European union and the treaty on the functioning of the European union 2012/C 326/01. 2012. https://eur-lex.europa. eu/legal-content/EN/TXT/PDF/?uri=CELEX:12012E/ TXT\&from $=$ PL.

[35] European Commission. Putting energy efficiency first: consuming better, getting cleaner. 2016. http://europa.eu/ $\mathrm{rapid} /$ press-release_MEMO-16-3986_en.htm.

[36] European Commission 2018. A Clean Planet for all. A European long-term strategic vision for a prosperous, modern, competitive and climate neutral economy Brussels, In-depth analysis in support of the Commission communication. 2018. p. 773. https://ec.europa.eu/clima/sites/default/files/docs/ pages/com_2018_733_analysis_in_support_en_0.pdf.

[37] European Parliament. MEPs set ambitious targets for cleaner, more efficient energy use. 2018. http://www. europarl.europa.eu/news/en/press-room/20180112IPR91629/ meps-set-ambitious-targets-for-cleaner-more-efficientenergy-use.

[38] European Parliament. Ambitne cele redukcji emisji gazów cieplarnianych do roku 2030. 2018. http://www.europarl. europa.eu/news/pl/headlines/society/20180208STO97442/ ambitne-cele-redukcji-emisji-gazow-cieplarnianych-doroku-2030Parlament Europejski. Traktat o funkcjonowaniu Unii Europejskiej: https://eur-lex.europa.eu/legal-content/ PL/TXT/?uri=celex:12012E/TXT.

[39] European Parliament. Rozporządzenie Parlamentu Europejskiego i Rady (UE) 2018/1999 z dnia 11 grudnia 2018 r. w sprawie zarządzania unią energetyczną $\mathrm{i}$ działaniami $\mathrm{w}$ dziedzinie klimatu. 2018. https://eur-lex.europa.eu/legalcontent/PL/TXT/PDF/?uri=CELEX:32018R1999\&from=EN.

[40] European environment agency. 2020. https://www.eea. europa.eu/data-and-maps/indicators/greenhouse-gasemission-trends-7/assessment.

[41] European Commision 2019, the European green deal, COM. 2019. 640 final, 11.12.2019.

[42] European Commission. The just transition Fund. 2019. https://ec.europa.eu/info/strategy/priorities-2019-2024/ european-green-deal/actions-being-taken-eu/just- transition-mechanism/just-transition-funding-sources pl\#specjalny-system-w-ramach-investeu.

[43] European Commission. Proposal for a regulation the European parliament and of the Council establishing the framework for achieving climate neutrality and amending regulation (EU) 2018/1999 (European climate law) brussels, 4.3.2020 COM(2020) 80 final2020/0036 (COD). 2020.

[44] European Commission. The Just Transition Mechanism: making sure no one is left behind. 2019. https://ec.europa.eu/ info/strategy/priorities-2019-2024/european-green-deal/ actions-being-taken-eu/just-transition-mechanism en.

[45] European Commission. Just Transition Mechanism: the EIB and the European Commission join forces in a proposed new public loan facility to finance green investments in the EU. 2020. https://ec.europa.eu/info/strategy/priorities-2019-2024/ european-green-deal/actions-being-taken-eu/justtransition-mechanism/just-transition-funding-sources_ pl\#specjalny-system-w-ramach-investeu.

[46] European Commission. New loan facility leveraged by the European Investment Bank (EIB). 2019. https://ec.europa.eu/ info/strategy/priorities-2019-2024/european-green-deal/ actions-being-taken-eu/just-transition-mechanism/justtransition-funding-sources_pl\#specjalny-system-w-ramachinvesteu.

[47] European Commission. Just Transition Mechanism: the EIB and the European Commission join forces in a proposed new public loan facility to finance green investments in the EU. 2020. https://www.eib.org/en/press/all/2020-130-commissi on-proposes-a-public-loan-facility-to-support-greeninvestments-together-with-the-eib.

[48] Michel Charles. 2020. https://www.consilium.europa.eu/pl/ press/press-releases/2020/05/13/intervention-at-theeuropean-parliament-on-the-video-conference-of-themembers-of-the-european-council-of-23-april-2020/.

[49] European Council. 2020. https://www.consilium.europa.eu/ media/47337/1011-12-20-euco-conclusions-pl.pdf.

[50] Carbon tracker. 2020. https://carbontracker.org/heres-whychinas-post-covid-19-stimulus-must-reject-costly-coalpower/.

[51] European Commission. EU Green Deal (carbon border adjustment mechanism). 2020. https://ec.europa.eu/info/law/ better-regulation/have-your-say/initiatives/12228-CarbonBorder-Adjustment-Mechanism.

[52] European Commission. The carbon border adjustment mechanism. 2021. https://ec.europa.eu/commission/ presscorner/detail/en/qanda_21_3661.

[53] European Commission. Study on the possibility to set up a carbon border adjustment mechanism on selected sectors. 2021.

[54] IDDRI. Coal transition in Poland report. 2018.

[55] Nettg. http://nettg.pl/news/153075/pre-cop24-europa-powin na-zweryfikowac-kurs; 2018.

[56] Bukowski M, Śniegocki A, Wetmańska Z. Od restrukturyzacji do trwałego rozwoju. Przypadek Górnego Śląska. WiseEuropa: WWF Polska; 2018.

[57] Kiewra D, Szpor A, Witajewski-Baktvilks J. Sprawiedliwa transformacja węgla w regionie śląskim. Implikacje dla rynku pracy. Instytut Badań Strukturalnych; 2019.

[58] Instytut Badań Strukturalnych Polska polityka energetyczna na rozdrożu: koszty i korzyści potencjalnej dekarbonizacji, Warszawa. 2018.

[59] Instytut Badań Strukturalnych Dekarbonizacja i zatrudnienie w górnictwie węla kamiennego w Polsce, IBS research report 01/2021. Instytut Badań Strukturalnych; 2021.

[60] JRC EU coal regions: opportunities and challenges Ahead. Joint Research Centre, European Union; 2018.

[61] Kapetaki Z, Ruiz P, et al. Clean energy technologies in coal regions: opportunities for jobs and growth. European Union: Joint Research Centre; 2020.

[62] Bednorz J. Decarbonisation of the European Union as a threat to its energy security and sustainable development. Energy Pol J 2012;15(3):181-95. 